\title{
Wiedergelesen: Eduard Zeis, Handbuch der plastischen Chirurgie, Berlin 1838
}

\author{
Reread: Eduard Zeis, Handbook of Plastic Surgery, Berlin 1838
}

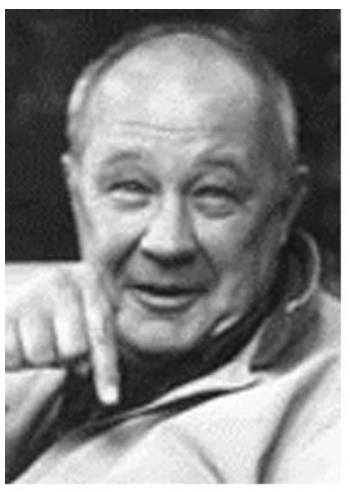

Dagobert Lindlau

Bibliography

DOI http://dx.doi.org/

$10.1055 / \mathrm{s}-0042-114030$

Online-Publikation: 19.10.2016

Handchir Mikrochir Plast Chir

2016; 48: 374-376

(c) Georg Thieme Verlag KG

Stuttgart $\cdot$ New York

ISSN 0722-1819

Correspondence

Dagobert Lindlau

Möschenfelder Strasse 66

85591 Vaterstetten

dı@dagobert-lindlau.com
Vor über 60 Jahren hat eine Chirurgin mit einer Reihe von gestielten Haut- und Gewebelappen die Amputation meines rechten Beins verhindert. Damals habe ich sie gefragt, was das denn für eine Chirurgie sei, diese sogenannte "plastische“, also „formende“ Chirurgie, die so etwas kann. Statt einer Antwort hatte Sie mir das „Handbuch der plastischen Chirurgie“ des Chirurgen Eduard Zeis (1807-1868) zum Lesen gegeben, in dessen Vorrede Johann Friedrich Dieffenbach (17921847) schreibt: „Ich halte es für völlig überflüssig, hier etwas zum Lob des Theils der Chirurgie zu sagen, welcher sich mit der Herstellung verstümmelter Theile des Körpers beschäftigt. Die neueste Zeit hat über seinen Werth entschieden. Er ist die höchste Blüthe der ganzen Chirurgie“. Jetzt, über 60 Jahre später, ist mir das Buch von Eduard Zeis wieder in die Hände gefallen. Wie damals hatte ich mich schon nach wenigen Seiten festgelesen. Gefesselt von der Klarheit und Integrität des Textes.

Zeis schreibt, als hätte er das Gebot des großen Stilisten Jacques Barzun (1907-2012!) vorausgeahnt, „Say what you mean: 'SIMPLE \& DIRECT'“, als hätte er gewusst, was Brand Blanshard (18921987) 50 Jahre nach ihm sagen wird: „Stil, das ist nicht die Feder am Hut, sondern die Feder am Pfeil, damit er genau trifft". Also nicht beeindrucken soll man seine Leser, sondern ihnen Genaues mit-teilen, also die eigenen Erkenntnisse mit ihnen teilen.

Mir geht es nicht um das Chirurgische. Da kann ich nicht mitreden. Aber eine genaue Beschreibung dessen, was ist oder wie etwas gemacht wird und warum es so und nicht anders gemacht werden sollte, das gehört auch ein wenig zu meinem Handwerk. Zeis macht uns allen mit seinem Handbuch vor, wie das geht. Nicht nur den Ärzten, sondern auch uns Journalisten. Neidvoll liest man seinen Text, nur um sich dann wieder mit den erbärmlichen Elaboraten medizinischer und journalistischer Stammelei abzufinden. Ja, auch mit den eigenen. Als wären hinkende Vergleiche und pleonastische Satz-Ungeheuer, gewürzt mit ein paar Fachausdrücken aus der Medizin oder der Politologie, allein schon der Beleg für besseres Wissen.

Der Philosoph Max Horkheimer, den ich meinen Lehrer nennen darf, war der Meinung, man brauche kein Abitur, um die Philosophie Schopenhauers oder Kants zu verstehen, wenn sie einem jemand erklärt, der sie begriffen hat. Horkheimer hatte nicht nur mein Herz, sondern auch meinen
More than 60 years ago, a woman surgeon prevented the amputation of my right leg with a series of skin and tissue flaps. I asked her what this so-called "plastic or forming surgery was" that could achieve something like that. Instead of answering, she lent me a copy of the book "Handbook of Plastic Surgery", by the surgeon Eduard Zeis (1807-1868). In the foreword to this book, Johann Friedrich Dieffenbach (1792-1847) writes: "I think it is totally superfluous to praise the area of surgery that deals with the restoration of mutilated parts of the body. We all know now how valuable this is. It is the epitome of all surgery".

Now, more than 60 years later, I have come across Eduard Zeis's book once again. As before, I was entranced after the first few pages - enthralled by the clarity and integrity of the text.

Zeis writes as if he had had a premonition of the commandment of the great stylist Jacques Barzun (1907-2012!): "Say what you mean: 'SIMPLE \& DIRECT"', or as if he had known what Brand Blanshard (1892-1987) would say 50 years after him: "Style is not the feather in the cap, but the feather in the arrow, so you hit the target dead on". The idea is not to impress your readers, but to impart precise information - to share your knowledge with them.

I am not discussing surgery - I'm not a plastic surgeon. But I do know about explaining things precisely - what something is or how it is done; why in this way and not in that way. In his handbook, Zeis shows how this is achieved. Not just for doctors, but also for us journalists. You get somewhat jealous when you read his text and then return to the bombastic hot air and incoherence emitted by some doctors and journalists. Including my own! Many people seem to think that they can prove their writing knowledge with lame comparisons and pleonastic monster sentences, flavoured with a few technical expressions from medicine or politology.

My mentor, the philosopher Max Horkheimer, was of the opinion that you did not need A-levels to understand Schopenhauer's or Kant's philosophy, as long you knew someone who had mastered it. Horkheimer convinced me both emotionally and intellectually when he said: "To recognise the truth, you don't just need perspicuity, but also naivety". Then, I had more than enough of the latter. The General Secretary of the British Academy of Forensic Sciences, Edward Francis Camps (1905-1972), once read out to me in his 
Kopf mit der Behauptung gewonnen: „Um eine Wahrheit zu erkennen, bedarf es nicht bloß des Scharfsinns, sondern auch der Naivität“. Von Letzterer hatte ich damals noch mehr als genug. Der Generalsekretär der British Academy of Forensic Sciences, Edward Francis Camps (1905-1972), hatte mir dann in seinem alten Coroners Court einen seitenlangen Sektionsbericht vorgelesen, um mir Ähnliches zu sagen, und mich gefragt, ob ich aus dem Text schlau würde. Ich musste es verneinen! „Der Kollege will sagen“, hatte es Francis Camps auf einen kurzen Nenner gebracht, „dass jemand dem Toten vor dessen Hinscheiden ein blaues Auge gehauen hat. Aber das schreibt er nicht, weil das Sie oder womöglich sogar die Geschworenen verstehen könnten“. Das Handbuch von Zeis macht klar, dass in der Mitte des Neunzehnten Jahrhunderts der Dreh- und Angelpunkt der plastischen Chirurgie ein Ersatz, die Rekonstruktion oder der Aufbau der Nase war. Die dabei gewonnenen Erkenntnisse wurden dann auch auf andere und ebenfalls sichtbare Bereiche des Körpers übertragen. Spätestens seit der Aufklärung war das uralte chirurgische Fach keine ketzerische Geheimwissenschaft mehr und die Nase war im doppelten Sinn des Wortes ein hervorragender Körperteil. Sie war nicht nur beim Kampf mit der blanken Waffe und bei kriegerischen Auseinandersetzungen gefährdet, sondern auch durch die Folgen der Syphilis, also der „Lustseuche“. Seit dem indischen Altertum galt das Abschneiden der Nase als gerechte Strafe für schwere Verbrechen. Trotz einem ganzen Jahrhundert der Aufklärung war aber auch noch im neunzehnten Jahrhundert ein Verlust der Nase im Krieg, durch die Syphilis oder im Zweikampf für eine Mehrheit von Abergläubigen immer noch ein Gottesurteil oder die Strafe für ein ungezügeltes Sexualleben. Immer noch sollte der durch den Verlust der Nase Entstellte dem Abscheu seiner Umgebung preisgegeben werden. Immer noch gab es den Verdacht, dass die plastische Chirurgie dem Allerhöchsten in den Arm fiel, wenn sie versuchte zu helfen. Zeis, Dieffenbach und ihre zeitgenössischen Kollegen hatten deshalb und trotz großen Respekts und zahlreicher Ehrungen und vielen akademischen Würden immer noch mit dem zu tun was schon Voltaire als die Schändlichkeit des Aberglaubens verflucht hatte. Zeis, Dieffenbach und ihre Zeitgenossen galten zwar als begnadete Chirurgen, aber bei einigen Dummköpfen immer noch als Rebellen. Sogar Erich Lexer (1867-1937) berichtet noch von religiösen Vorurteilen bei seinen Versuchen fremdes Gewebe zu verpflanzen. Die Aufklärung hatte zwar die Finsternis des Aberglaubens ein wenig aufgehellt, mehr aber nicht. Eine neue „Eclipse of Reason“ (Horkheimer), eine neue Verfinsterung der Vernunft, durch Reklame, Propaganda, Schönfärberei und andere Methoden der Desinformation, hatte begonnen. Die alte hatte dazu geführt, dass der große Bologneser Chirurg Tagliacozzi in ungeweihter Erde verscharrt werden musste. Die neue verhieß Lebensglück durch Körbchengröße oder Nasenform.

Der Aufbau des „Handbuchs der plastischen Chirurgie“ von Zeis ist bezeichnend für die Redlichkeit des Autors. Seiten um Seiten führt er zu Beginn seines Buchs unter dem Titel „Die Litteratur (sic) der plastischen Chirurgie“ die Namen all derer auf, deren Erfahrungen er sich und seinen Lesern zunutze macht. Nicht irgendwo hinten versteckt oder gar unterschlagen, wie neuerdings bei Plagiaten üblich. Nicht nur die Zeitgenossen, von Johann Friedrich Dieffenbach (1792-1847) über Ferdinand von Gräfe (1767-1840) bis Friedrich August von Ammon (1799-1861) werden ausführlich genannt, sondern auch alle ihre Vorgänger. Zeis merkt ehrlich an, was die plastische Chirurgie (damals noch) nicht konnte und wo sie (noch) an ihre Grenzen stieß. old Coroners Court a several sided dissection report, to give me the same idea, and asked me if I was any the wiser. I had to say no! Francis Camps summarised it as follows: "My colleague wanted to explain that someone had given the victim a black eye before his death. But he doesn't write that, because even the jurors might understand it".

Zeis's handbook clarifies that in the middle of the $19^{\text {th }}$ century the core of plastic surgery was the replacement, reconstruction or assembly of the nose. The resulting knowledge and expertise was then applied to other equally visible areas of the body. At least since the Enlightenment, the ancient surgical subject was no longer a heretical secret science and the nose was an outstanding part of the body - in both senses of the word. It was not only at risk when fighting with the sword or during battles, but also as a consequence of syphilis. Since antiquity in India, cutting off the nose was regarded as a just punishment for severe crime. Even in the $19^{\text {th }}$ century, a hundred years after the start of the Enlightenment, superstitious people considered that the loss of the nose in war, from syphilis or in a duel, was God's judgement or punishment for licentious sexual behaviour. Someone disfigured by the loss of his nose was still revolting to his fellow men. It was suspected that the plastic surgeon was working against the almighty when he did his best to help the victim. Zeis, Dieffenbach and their contemporaries won great respect, numerous honours and many academic titles but still had to struggle against what Voltaire had cursed as the infamy of superstition. Zeis, Dieffenbach and their contemporaries may have been regarded as talented surgeons, but some fools still regarded them as rebels. Even Erich Lexer (1867-1937) reported religious prejudice in his attempts to transplant foreign tissue. The Enlightenment may have illuminated the darkness of superstition a little - but only a little. A new "eclipse of reason" (Horkheimer), a new darkening of reason, had started - with advertisements, propaganda, embellishments and other methods of disinformation. The old form of superstition had meant that the Bologna surgeon Tagliacozzi had to be buried in unhallowed earth. The new form promised good fortune with your cup size or the shape of your nose.

The structure of Zeis' "Handbook of Plastic Surgery" shows the author's honesty. At the start of his book, he has a section entitled "The Litterature (sic) of Plastic Surgery", which lists the names of all those on whose experience he and his readers could draw. This was not hidden in the back or even suppressed, as is now usual in plagiary. Not only his contemporaries - from Johann Friedrich Dieffenbach (1792-1847), to Ferdinand von Gräfe (1767-1840), to Friedrich August von Ammon (1799-1861) are mentioned in detail, but also all their predecessors. Zeis honestly states what plastic surgery could not yet do (then), and where it had reached its limits.

He wrote: "Surgery can replace a destroyed nose, lips, eyelids and various other body parts by transplanting and incorporating pieces of skin at the site of the defect. This can lead to a considerable improvement in the unpleasant appearance and the new tissue can more or less take on the requisite functions. However, the surgeon can never perfectly restore the original situation, as formed in natural creation and accordance with the wonderful laws of structural development". He had no way of knowing about sterile surgery, antibiotics, modern anaesthesia or the possibilities presented by stem cell therapy.

Zeis supported the term "plastic surgery" as being "the best descriptive expression". He mentions Tagliacozzi‘s $16^{\text {th }}$ century 
„Wohl aber vermag die operative Chirurgie“, schreibt er, „zerstörte Nasen, Lippen, Wangen, Augenlider und verschiedene andere Theile durch Verpflanzung durch Anheilung von Hautstücken an die Stelle des Defectes in dem Masse zu ersetzen, dass der durch die Verstümmlung bewirkte widrige Anblick um ein Bedeutendes verbessert, und die Funktionen, welchen jene Theile vorstanden, durch die neugebildeten mehr oder weniger vertreten werden“. Aber meint er: „... niemals vermag die Kunst das vollkommen wieder herzustellen. Was die schaffende Natur nach den wunderbaren Gesetzen der Bildung erzeugt hatte“. Vom keimarmen Operieren, von Antibiotika, von den neuen Möglichkeiten der Anästhesie und von der Hoffnung auf eine Stammzellen-Therapie konnte er noch nichts ahnen.

Zeis begründet den Namen „plastische Chirurgie“ „als den am allgemeinsten bezeichnenden Ausdruck“. Er erwähnt Tagliacozzis plastisch-chirurgische Operationslehre aus dem 16. Jahrhundert: „Chirurgia curtorum per insitionem“. Und er wendet sich energisch gegen eine Schwemme von neuen Bezeichnungen wie „Blepharoplastik, Chiloplastik usw.“. Wie hätte ihm wohl der Begriff „Ästhetische Chirurgie“ gefallen? Im Gegensatz wozu? Zur „unästhetischen“ Chirurgie? Ganz zu schweigen von „Schönheitschirurgie“.

Zeis zitiert ganze Passagen aus dem lateinischen Original Tagliacozzis „De curtorum chirurgia“ und aus französischen Texten. Er konnte offensichtlich davon ausgehen, dass die damaligen deutschen Chirurgen nicht nur Latein verstanden, sondern auch französische Arbeiten lesen konnten.

Er erklärt sogar, warum er den Holzschnitt zur bildlichen Darstellung gewählt hatte: Weil man dann die erläuternde Zeichnung zum Text stellen könne und nicht an anderer Stelle mühsam Kupferdrucke herausklappen müsse. Es sei schließlich, entschuldigt er sich, nicht seine Aufgabe Porträts der Patienten zu liefern, sondern die Schnittführung von Operationen.

Gegen Ende des knapp 600 Seiten umfassenden „Handbuchs der plastischen Chirurgie" werden zum ersten Mal Eingriffe an der Hand als zur plastischen Chirurgie gehörig erwähnt. Es geht vor allem um die von Guillome Dupuytren (1777-1835) entwickelten Operationsmethoden, um die später nach ihm benannten Kontrakturen zu heilen. Sie wurden auch von Dieffenbach erfolgreich durchgeführt. „Die grüßende Hand, der besiegelnde Handschlag gehörten zu einer gesunden Funktion der äußeren Erscheinung“" (Milton Edgerton).

Das letzte Wort aber erteilt Zeis dem Bologneser Chirurgen Gaspare Tagliacozzi: „Wir glauben den Standpunkt, den sie (die plastische Chirurgie) für jetzt einnimmt, in diesem Buche bezeichnet zu haben“, schreibt er und fügt mit der für ihn typischen Bescheidenheit Tagliacozzis Warnung hinzu: „sed, ut neque in universa medicina, imo in omni actionum genere. Cuncta firma sunt, et aeterna, ita neque hic, quod jam diximus, perpetuum est. (Taliacot.lib.II.c13.pag.48.)“

Wie in der ganzen Medizin und bei allem, was man tut oder sagt, nichts gilt für alle Ewigkeit. Zeis und Tagliacozzi wussten, dass die Medizin keine exakte, sondern eine historische Wissenschaft ist, die ihre Aussagen entsprechend dem jeweiligen Stand der Erkenntnis im Lauf der Zeit ändern muss. Nicht nur das. Sie muss das auch zugeben, wenn sie ehrlich bleiben will. handbook of plastic surgery: „Chirurgia curtorum per insitionem". And he was vigorously opposed to a swarm of new expressions, such as "blepharoplasty, cheiloplasty etc.". Would he have liked "aesthetic surgery"? In contrast to "unaesthetic surgery"? Certainly not "beauty surgery"!

Zeis cited whole passages from the Latin original of Tagliacozzi's "De curtorum chirurgia" and from French texts. He could evidently assume that the German surgeons of his day not only understood Latin, but could read French articles.

He even explained why he had selected the woodcut for illustrations. This meant that the explanatory drawing could be placed next to the text and the reader was not forced tediously to unfold copperplates from elsewhere. He apologized that it was not his job to supply portraits of the patients, but to show incisions during an operation.

Towards the end of the just under 600 pages of the "Handbook of Plastic Surgery", the author mentions operations on the hand as part of plastic surgery. This was mainly about the operation developed by Guillome Dupuytren (1777-1835), in order to cure the eponymous contraction. This was also successfully performed by Dieffenbach. "A friendly or sealing handshake was considered part of a healthy function of appearance" (Milton Edgerton).

However, Zeis allows the Bologna surgeon Gaspare Tagliacozzi the last word. Zeis wrote: "We think we have provided an adequate description of the current status of plastic surgery". But then adds, with his typical modesty, Tagliacozzi's warning: "sed, ut neque in universa medicina, imo in omni actionum genere. Cuncta firma sunt, et aeterna, ita neque hic, quod jam diximus, perpetuum est. (Taliacot.lib.II.c13.pag.48.)"

"But nothing lasts for ever - as in all of medicine and everything else that we do or say".) Zeis and Tagliacozzi were well aware that medicine is not an exact, but an historical, science, that has to modify its conclusions over time as knowledge changes. Not only that. It must admit this, if it wants to be honest.

Dagobert Lindlau hat 1987 den Bestseller „DER MOB; Recherchen zum Organisierten Verbrechen“ veröffentlicht und damit eine rot/schwarze Koalition der Verdrängung beendet, die diese Bedrohung aus völlig unterschiedlichen ideologischen Gründen geleugnet hatte.

Sein Theaterstück „St Pauli Saga“ wurde vom Deutschen Schauspielhaus Hamburg mit Eva Mathes und Joseph Bierbichler in den Hauptrollen 1997 uraufgeführt. Lindlau moderierte viele Jahre den WELTSPIEGEL der ARD und berichtete als Chefreporter des BR-Fernsehens für die ARD aus Krisengebieten. Unter anderem wurde ihm 1986 die „besondere Ehrung des Grimme-Preises für hervorragende Verdienste um das Fernsehen in der Bundesrepublik Deutschland“ verliehen. 